\title{
EKSTRAK ETANOL DAUN JERUK PURUT (Citrus hystrix D.C) MENGHAMBAT PERTUMBUHAN Bacillus cereus: UJI IN VITRO
}

\author{
Ridha Nugraheni ${ }^{* \varpi}$, Noorhamdani** Hanif**
}

\begin{abstract}
Abstrak
Hospital-acquired infections (HAls) merupakan infeksi yang terjadi pada pasien saat menerima perawatan di rumah sakit dalam waktu lebih dari 48 jam. Sebagian besar HAls disebabkan oleh bakteri yang resisten terhadap antibiotik. Salah satu penyebabnya adalah bakteri Bacillus cereus. B. cereus memiliki dua jenis toksin yang menyebabkan gejala gastrointestinal. Pada individu immunocompromised, $B$. cereus dapat menyebabkan sejumlah infeksi sistemik dan lokal fatal. Upaya untuk mengurangi resistensi bakteri adalah dengan mengurangi penggunaan antibiotik yang tidak rasional, salah satunya dengan menggunakan alternatif pengobatan herbal. Daun jeruk purut (Citrus hystrix D.C) mengandung flavonoid, alkaloid, tannin, kuinon, dan terpenoid yang terbukti memiliki efek antimikroba. Penelitian ini bertujuan untuk mengetahui aktivitas antibakteri ekstrak etanol daun jeruk purut terhadap $B$. cereus secara in vitro. Dalam penelitian ini digunakan 7 perlakuan yaitu konsentrasi 3,125\%; 6,25\%; $12,5 \% ; 25 \% ; 50 \% ; 100 \% ; 0 \%$ sebagai kontrol negatif, dan antibiotik kloramfenikol $10 \mathrm{mg} / \mathrm{mL}$ sebagai kontrol positif. Pengulangan sebanyak empat kali menggunakan metode difusi sumuran. Hasil menunjukkan rata-rata terbentuknya diameter zona hambat pertumbuhan pada konsentrasi $6,25 \% ; 12,5 \% ; 25 \% ; 50 \% ; 100 \%$ berturut-turut 5,93 mm; $7,05 \mathrm{~mm} ; 8,23 \mathrm{~mm} ; 10,41 \mathrm{~mm} ; 12,00 \mathrm{~mm}$. Uji post hoc Tukey HSD menunjukkan ekstrak mulai efektif sebagai antibakteri terhadap B. cereus pada konsentrasi 6,25\% $(p<0,05)$. Uji korelasi Pearson menunjukkan adanya hubungan signifikan antara konsentrasi ekstrak terhadap zona hambat pertumbuhan $(p<0,05)$. Disimpulkan bahwa ekstrak etanol daun jeruk purut efektif sebagai antibakteri $B$. cereus secara in vitro dan signifikan bila dibandingkan dengan kloramfenikol.
\end{abstract}

Kata kunci: antibakteri, Bacillus cereus, daun jeruk purut (Citrus hystrix D.C)

\section{ETHANOL EXTRACT OF KAFFIR LIME (Citrus hystrix D.C) LEAVES INHIBIT THE GROWTH OF Bacillus cereus: IN VITRO STUDY}

\begin{abstract}
Hospital-acquired infections (HAls) are infections that occur in patients when they receive hospital treatment for more than 48 hours. Most HAls are caused by bacteria that are resistant to antibiotics. One of the causes is Bacillus cereus. B. cereus has two types of toxins that can cause gastrointestinal symptoms. In immunocompromised persons, $B$. cereus can cause several fatal systemic and local infections. One of the efforts to reduce bacterial resistance is by reducing the irrational use of antibiotics using herbal medicine as an alternative. Kaffir lime (Citrus hystrix D.C) leaves contain flavonoids, alkaloids, tannins, quinones, and terpenoids which are proven to have antimicrobial effects. This in vitro study is aimed to determine the antibacterial activity of ethanol extract of kaffir lime leaves against $B$. cereus. In this study, 7 different treatments were used with the concentrations of $3.125 \% ; 6.25 \% ; 12.5 \% ; 25 \% ; 50 \% ; 100 \% ; 0 \%$ as negative control, and $10 \mathrm{mg} / \mathrm{mL}$ of chloramphenicol as positive control. It was repeated four times using the well diffusion method. The results showed that the average diameter of inhibition zone was formed at a concentration of $6.25 \% ; 12.5 \% ; 25 \% ; 50 \% ; 100 \%$, consecutively: $5.93 \mathrm{~mm} ; 7.05 \mathrm{~mm} ; 8.23 \mathrm{~mm} ; 10.41 \mathrm{~mm}$; $12.00 \mathrm{~mm}$. Post hoc Tukey HSD test showed that the extract began to be effective as an antibacterial against $B$. cereus at a concentration of $6.25 \%(p<0.05)$. Pearson correlation test showed a significant relationship between the concentration of extract and the growth inhibition zone $(p<0.05)$. In conclusion, ethanol extract of kaffir lime leaves was effective as an antibacterial against $B$. cereus in vitro and significant when compared to chloramphenicol.
\end{abstract}

Keywords: antibacteria, Bacillus cereus, kaffir lime (Citrus hystrix D.C) leaves

* Program Studi Pendidikan Dokter (S1), Fakultas Kedokteran, Universitas Brawijaya

** Departemen Mikrobiologi, Fakultas Kedokteran, Universitas Brawijaya

${ }^{* * *}$ Departemen Anestesiologi dan Terapi Intensif, Fakultas Kedokteran, Universitas Brawijaya

E-mail: ridhanugraheni@student.ub.ac.id 


\section{Pendahuluan}

Hospital-acquired infections atau HAls merupakan infeksi yang terjadi pada pasien saat menerima perawatan kesehatan yang pertama kali muncul dalam 48 jam atau lebih setelah masuk rumah sakit, atau dalam 30 hari setelah menerima perawatan kesehatan. Sebagian besar HAls disebabkan oleh bakteri yang resisten terhadap antibiotik dan dapat menyebabkan sepsis hingga kematian. Faktor utama yang memicu penyebab kontaminasi silang ini adalah karena turunnya respons imun pasien (immunocompromised).1,2

Bacillus cereus merupakan bakteri basil Gram positif yang dapat ditemukan di hampir seluruh permukaan di lingkungan. $B$. cereus memiliki dua jenis toksin utama (toksin emetik dan diare) yang menjadi faktor virulensi bakteri ini. ${ }^{3}$ Kedua toksin ini menyebabkan timbulnya gejala gastrointestinal pada individu yang terinfeksi. Selain itu, B. cereus juga dapat menyebabkan infeksi lokal dan sistemik seperti septikemia, endoftalmitis, pneumonia, endocarditis, meningitis dan ensefalits terutama pada individu immunocompromised seperti neonatus yang mengakibatkan kematian sekitar $10 \%$ dari kasus. ${ }^{3}$

Infeksi $B$. cereus umumnya diobati dengan antibiotik. Namun, seiring meningkatnya resistensi terhadap antibiotik, infeksi menjadi lebih sulit diobati. Untuk mengontrol kejadian resistensi antibiotik lebih lanjut, pemberian antibiotik secara rasional harus diterapkan, seperti dengan memperhatikan dosis optimal, interval pemberian obat dan durasi pemberian terapi. Untuk mengurangi pemakaian antibiotik berlebih dan meminimalisir kejadian resistensi antibiotik, maka dibutuhkan alternatif pengobatan lain seperti penggunaan obat-obatan herbal yang memiliki efek samping minimal, salah satunya daun jeruk purut (Citrus hystrix D.C).

Menurut hasil penelitian, ditemukan beberapa zat aktif yang terkandung dalam ekstrak etanol daun jeruk purut (Citrus hystrix D.C), antara lain ialah alkaloid, karbohidrat, flavonoid, glikosida, fitosterol, tannin, kuinon, monoterpenoid dan seskui-terpenoid. 4,5 Beberapa dari zat aktif tersebut diketahui memiliki aktivitas antibakteri yang telah diuji efeknya terhadap bakteri baik Gram positif maupun Gram negatif secara in vitro. 6,7

Tujuan dari penelitian ini adalah untuk mengetahui aktivitas antibakteri ekstrak etanol daun C. hystrix D.C terhadap B. cereus dan mengetahui hubungan antara konsentrasi ekstrak etanol C. hystrix D.C dengan diameter zona hambat pertumbuhan bakteri $B$. cereus yang terbentuk. Berdasarkan dari latar belakang yang ada, maka dianggap perlu untuk melakukan uji efektivitas antibakteri $C$. hystrix terhadap $B$. cereus secara in vitro.

\section{Bahan dan Metode}

\section{Rancangan Penelitian}

Penelitian ini merupakan penelitian true experimental untuk mengetahui aktivitas antibakteri ekstrak etanol daun C. hystrix D.C terhadap $B$. cereus secara in vitro menggunakan metode uji sensitivitas difusi sumuran.

\section{Sampel Penelitian}

Sampel yang digunakan dalam penelitian ini adalah biakan strain B. cereus NTCC 8055 yang didapatkan dari Balai Laboratorium Kesehatan dan Kalibrasi Yogyakarta yang telah melalui uji isolasi dan identifikasi dan mendapatkan sertifikat hasil uji, yaitu menggunakan metode identifikasi Gram (teridentifikasi batang Gram positif ditunjukkan oleh Gambar 1) dan isolasi pada medium Blood Agar Plate (teridentifikasi zona hemolisis penuh ( $\beta$ ) ditunjukkan pada Gambar 2).

\section{Variabel Penelitian}

Variabel penelitian terdiri dari ekstrak etanol daun C. hystrix D.C dengan konsentrasi $0 \% ; 3,125 \% ; 6,25 \% ; 12,5 \% ; 25 \% ; 50 \%$; $100 \%$ sebagai variabel bebas. 
Lalu, zona hambat pertumbuhan bakteri $B$. cereus yang terbentuk sebagai variabel tergantung.

\section{Lokasi Penelitian}

Penelitian ini dilakukan di Laboratorium Mikrobiologi Klinik, Fakultas Kedokteran, Universitas Brawijaya, Malang.

\section{Identifikasi Bakteri Uji}

Untuk memastikan bakteri yang diujikan benar $B$. cereus, dilakukan identifikasi bakteri uji dengan metode pewarnaan Gram (Gambar 1) dan penanaman pada medium BAP (Gambar 2).

\section{Pembuatan Ekstrak Etanol Daun Jeruk Purut} (C. hystrix D.C)

Daun jeruk purut diperoleh dari UPT Materia Medika Kota Batu, Malang. Daun jeruk purut sejumlah 200 gram ditimbang dan dibersihkan dengan air mengalir, ditiriskan dan dipotong-potong menjadi bagian kecil. Sampel daun jeruk purut kemudian dikeringkan dalam oven pada suhu $40-60{ }^{\circ} \mathrm{C}$ dan diblender hingga menjadi sediaan serbuk. Pembuatan ekstrak dilakukan dengan metode maserasi dengan cara merendam 200 gram serbuk daun jeruk purut ke dalam bejana, kemudian sampel kering dicampur dengan 1 L pelarut etanol $96 \%$ dan dikocok selama 30 menit, kemudian direndam semalam hingga mengendap. Lapisan atas yang terpisah merupakan campuran dari pelarut dan senyawa aktif. Lapisan ini diambil dan diulang langkah yang sama hingga sebanyak 3 kali. Setelah itu, hasil yang diperoleh dimasukkan ke dalam labu evaporasi dan dipasang pada evaporator. Proses evaporasi ini dilakukan untuk memisahkan pelarut etanol $96 \%$ dengan zat aktif daun jeruk purut yang diinginkan. ${ }^{8}$

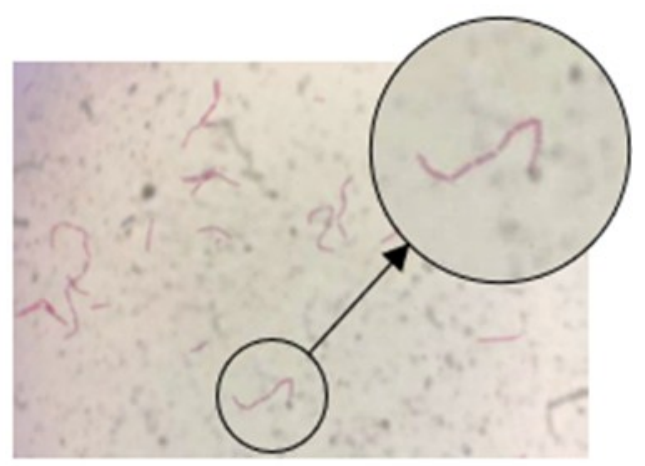

Gambar 1. Hasil pewarnaan Gram bakteri Bacillus cereus didapatkan gambaran bakteri basil Gram positif (1000x)

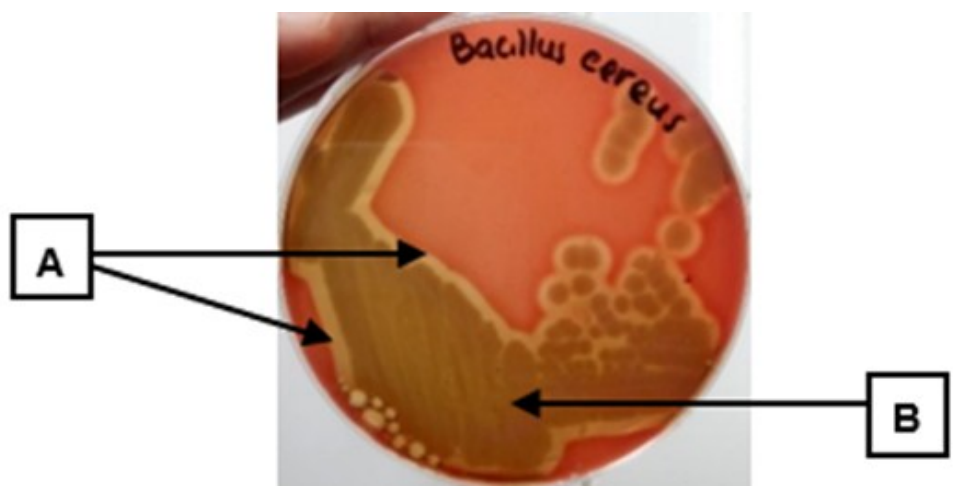

Gambar 2. Hasil uji aktivitas hemolitik pada bakteri Bacillus cereus

Keterangan. Didapati zona bening (A) berukuran 2-4 mm di sekitar pertumbuhan koloni bakteri Bacillus cereus $(B)$ yang menandakan adanya zona hemolisis penuh $(\beta)$ 


\section{Persiapan Bakteri Uji}

Uji sensitivitas antibakteri dengan metode difusi sumuran membutuhkan suspensi bakteri $B$. cereus dengan kepadatan $10^{5} \mathrm{CFU} /$ $\mathrm{mL}$. Pembuatan suspensi bakteri uji dilakukan dengan langkah-langkah sebagai berikut: koloni bakteri $B$. cereus dimasukkan ke tabung reaksi steril berisi nutrient broth menggunakan ose dan dicampur denga vortex, kemudian diinkubasi pada suhu 35-37 ${ }^{\circ} \mathrm{C}$ selama 18-24 jam. Untuk mendapatkan hasil konsentrasi bakteri sebesar $10^{5} \mathrm{CFU} /$ $\mathrm{mL}$, suspensi diencerkan dengan menggunakan rumus pengenceran yang setara dengan nilai OD sebesar $0,1 .{ }^{9}$

\section{Uji Aktivitas Antibakteri}

Pembuatan konsentrasi ekstrak dilakukan dengan cara melarutkan ekstrak etanol daun jeruk purut $(100 \%)$ dengan akuades sehingga diperoleh konsentrasi $50 \%, 25 \%$, $12,5 \%, 6,25 \%, 3,125 \%$ dengan pengenceran bertingkat. Kontrol positif yang digunakan adalah antibiotik kloramfenikol dan kontrol negatif akuades $(0 \%)$.

Uji sensitivitas antibakteri dilakukan dengan menggunakan metode difusi sumuran. Media dipersiapkan dengan mencampurkan suspensi bakteri uji sebanyak $0,5 \mathrm{~mL}$ dengan $25 \mathrm{~mL}$ nutrient agar cair pada 5 petri dish berbeda. Setelah media memadat, dibuat 7 lubang sumuran dengan diameter $5 \mathrm{~mm}$ dan kedalaman $4 \mathrm{~mm}$. Untuk media kontrol positif, dibuat 4 lubang sumuran. Kemudian pada masing-masing lubang sumuran yang telah dibuat, dimasukkan berbagai konsentrasi ekstrak daun jeruk purut dan juga dosis antibiotik 200 $\mathrm{mg} / \mathrm{mL}, 10 \mathrm{mg} / \mathrm{mL}, 1 \mathrm{mg} / \mathrm{mL}$, dan $0,1 \mathrm{mg} / \mathrm{mL}$. Media sumuran diinkubasi pada suhu $37^{\circ} \mathrm{C}$ selama 18-24 jam dan diukur diameter zona hambat pertumbuhan yang terbentuk menggunakan jangka sorong. ${ }^{10}$

\section{Hasil}

Hasil uji sensitivitas antibakteri ekstrak etanol daun jeruk purut terhadap bakteri $B$. cereus secara in vitro dengan konsentrasi ekstrak daun jeruk purut $100 \%, 50 \%, 25 \%$, $12,5 \%, 6,25 \%, 3,125 \%, 0 \%$ (kontrol negatif), dan kontrol positif antibiotik kloramfenikol yang mulai sensitif pada dosis $10 \mathrm{mg} / \mathrm{mL}$ menunjukkan hasil pada Gambar 3 dengan keterangan rata-rata diameter yang disajikan pada Tabel 1.

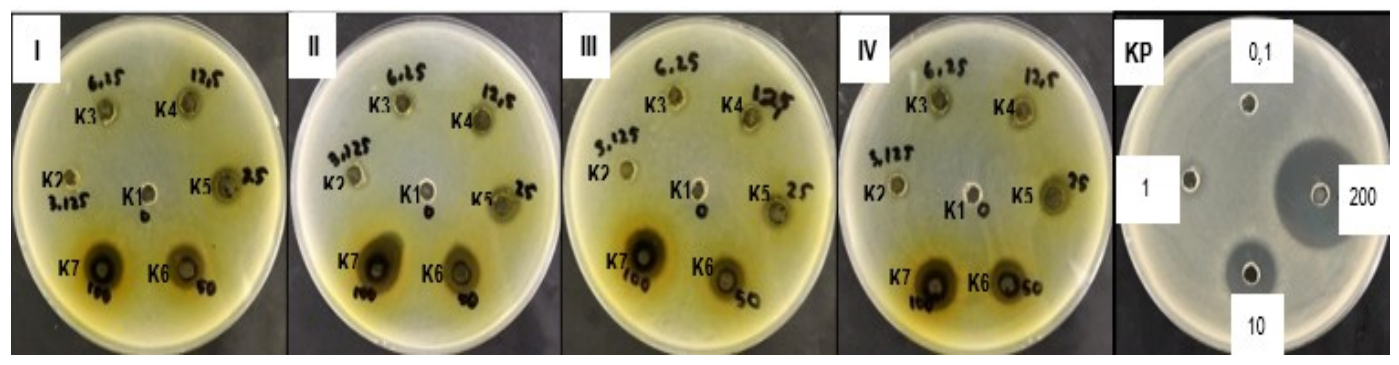

Gambar 3. Hasil uji difusi sumuran 7 konsentrasi berbeda dari ekstrak etanol daun jeruk purut dengan 4 kali pengulangan (I-IV) dan kontrol kloramfenikol (KP) terhadap Bacillus cereus Keterangan: (I-IV) merupakan hasil uji aktivitas antibakteri ekstrak etanol daun jeruk purut terhadap bakteri B. cereus dengan pengulangan 4 kali. K1: Ekstrak daun jeruk purut konsentrasi $0 \%$. K2: Ekstrak daun jeruk purut konsentrasi 3,125\%. K3: Ekstrak daun jeruk purut konsentrasi 6,25\%. K4: Ekstrak daun jeruk purut konsentrasi 12,5\%. K5: Ekstrak daun jeruk purut konsentrasi 25\%. K6: Ekstrak daun jeruk purut konsentrasi 50\%. K7: Ekstrak daun jeruk purut konsentrasi 100\%. (KP) merupakan merupakan kontrol positif menggunakan antibiotik kloramfenikol dengan berbagai dosis, sensitif mulai dosis $10 \mathrm{mg} / \mathrm{mL}$ 
Tabel 1. Hasil pengukuran diameter zona hambat pertumbuhan

\begin{tabular}{|c|c|c|c|c|c|}
\hline \multirow[t]{2}{*}{ Perlakuan } & \multicolumn{4}{|c|}{$\begin{array}{l}\text { Diameter Zona Hambat Pertumbuhan } \\
(\mathrm{mm})\end{array}$} & \multirow[t]{2}{*}{ Rata-Rata } \\
\hline & I & $\|$ & III & IV & \\
\hline $\mathrm{KN}(0 \%)$ & 0 & 0 & 0 & 0 & 0 \\
\hline K1 $(3,125 \%)$ & 0 & 0 & 0 & 0 & 0 \\
\hline K2 (6,25\%) & $5,57^{*}$ & $5,94^{*}$ & $5,89^{*}$ & $6,30^{*}$ & $5,93^{*}$ \\
\hline K3 $(12,5 \%)$ & $6,91^{*}$ & $7,30^{*}$ & $6,79^{*}$ & $7,21^{*}$ & $7,05^{*}$ \\
\hline K4 (25\%) & $8,17^{*}$ & $8,54^{*}$ & $7,90^{*}$ & $8,29^{*}$ & $8,23^{*}$ \\
\hline K5 (50\%) & $10,41^{*}$ & $10,58^{*}$ & $10,22^{*}$ & $10,42^{*}$ & $10,41^{*}$ \\
\hline K6 (100\%) & $11,54^{*}$ & $11,89^{*}$ & $12,19^{*}$ & $12,35^{*}$ & $12,00^{*}$ \\
\hline KP (Kloramfenikol $10 \mathrm{mg} / \mathrm{mL}$ ) & & & $14,43^{*}$ & & \\
\hline
\end{tabular}

Keterangan: KN: Kontrol Negatif, KP: Kontrol Positif, K1-6: 6 konsentrasi berbeda ekstrak etanol daun jeruk purut yang diujikan. *: Hasil signifikan terhadap kelompok kontrol negatif $(p<0,05)$

\section{Analisis Data}

Uji statistik yang pertama kali dilakukan adalah uji normalitas dan homogenitas. Uji normalitas dilakukan menggunakan uji Saphiro-Wilk dan menunjukkan data berdistribusi normal $(p>0,05)$. Uji homogenitas dilakukan menggunakan Lavene test dan didapatkan hasil bervarian homogen $(p>$ $0,05)$. Dengan data penelitian terdistribusi normal dan homogen, maka uji statistik menggunakan uji parametrik yaitu uji komparasi one way ANOVA, uji post hoc Tukey HSD, dan uji korelasi Pearson. Uji komparasi oneway ANOVA menunjukkan bahwa setidaknya terdapat 2 kelompok yang memiliki rerata zona hambat pertumbuhan yang berbeda secara signifikan $(p<0,05)$. Uji korelasi post hoc Tukey HSD menunjukkan adanya perbedaan kelompok perlakuan secara signifikan dimulai dari konsentrasi $6,25 \%(p<$ 0,05). Uji korelasi Pearson menunjukkan adanya hubungan yang signifikan antara konsentrasi ekstrak terhadap zona hambat pertumbuhan yang terbentuk $(p<0,05)$. Pada hasil uji tersebut didapatkan nilai $R$ (koefisien korelasi) yang bersifat positif sebesar 0,809 (pada selang 0,8-1,0) yang menunjukkan bahwa pemberian ekstrak daun jeruk purut (Citrus hystrix D.C) dengan zona hambat pertumbuhan yang terbentuk memiliki hubungan yang sangat kuat. ${ }^{11}$

Uji regresi liniear digunakan untuk menghitung besarnya pengaruh variabel bebas terhadap variabel tergantung pada penelitian ini. Hasil uji regresi linear didapatkan persamaan $Y=3,255+0,106 X$, yang artinya tanpa memperhatikan pengaruh dari konsentrasi ekstrak etanol $(X=0)$, zona hambat pertumbuhan terbentuk rata-rata sebesar 3,255 mm, dan besar pengaruh untuk setiap pertambahan $1 \%$ konsentrasi ekstrak etanol $(X=1,2,3$, dst. $)$, zona hambat pertumbuhan akan meningkat sebesar 0,106 $\mathrm{mm}$. Kurva persamaan regresi linear dapat dilihat pada Gambar 4.

\section{Pembahasan}

Hasil penelitian menunjukkan terbentuknya zona hambat pertumbuhan yang berbanding lurus dengan besar konsentrasi ekstrak yang digunakan. Artinya semakin besar konsentrasi ekstrak daun jeruk purut, semakin besar pula diameter zona hambat pertumbuhan yang terbentuk. Penelitian herbal lain menggunakan ekstrak daun nipah terhadap bakteri $B$. cereus yang memperoleh hasil zona hambat pertumbuhan meningkat seiring bertambahnya konsentrasi ekstrak daun nipah. ${ }^{12}$ 


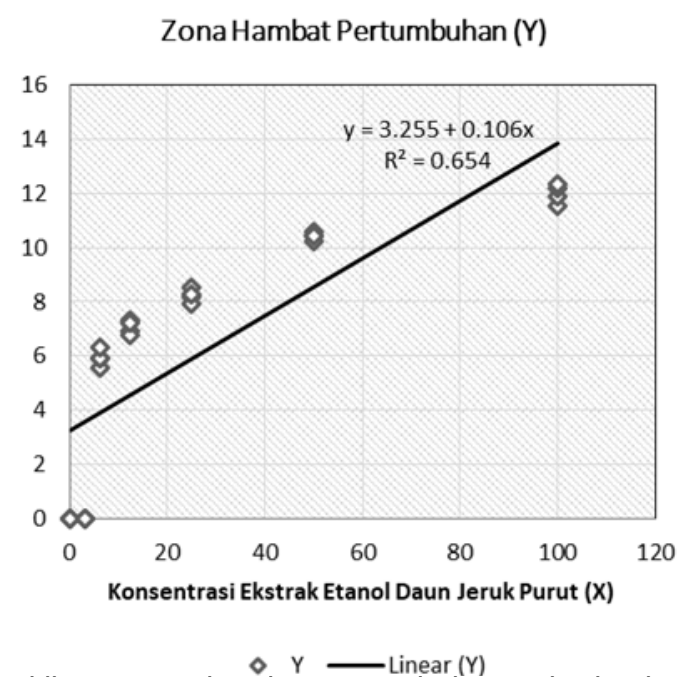

Gambar 4. Kurva regresi linear zona hambat pertumbuhan terhadap konsentrasi ekstrak etanol daun jeruk purut

Keterangan: Titik-titik plot data membentuk pola garis lurus yang berdekatan dengan garis linear persamaan. Hal ini menunjukkan adanya hubungan linear dan positif antar kedua variabel

Peningkatan diameter zona hambat pertumbuhan ini dimungkinkan karena seiring tingginya konsentrasi ekstrak yang digunakan maka semakin banyak kandungan zat antibakteri di dalamnya.

Menurut kategori sensitivitas antibakteri berdasarkan diameter zona hambat pertumbuhan yang terbentuk, perlakuan pada konsentrasi $6,25 \%, 12,5 \%$ dan $25 \%$ termasuk dalam sensitivitas antibakteri sedang (diameter 5-10 mm), sementara konsentrasi $50 \%$ dan $100 \%$ termasuk dalam sensitivitas antibakteri kuat (diameter 10-20 mm). ${ }^{13}$

Hasil penelitian tersebut menunjukkan adanya aktivitas antimikroba ekstrak etanol daun jeruk purut (Citrus hystrix D.C) terhadap Bacillus cereus secara in vitro. Kesimpulan ini dibuktikan oleh hasil analisis data uji statistik yang menunjukkan adanya signifikansi $(p<$ 0,05 ) pada konsentrasi yang diujikan (Tabel 1), yaitu konsentrasi $6,25 \%, 12,5 \%, 25 \%$, $50 \%$, dan $100 \%$. Pada perlakuan kontrol positif, didapatkan data diameter zona hambat pertumbuhan yang terbentuk terhadap pemberian antibiotik kloramfenikol $10 \mathrm{mg} / \mathrm{mL}$ yang menunjukkan perbedaan signifikan $(p<0,05)$ terhadap pemberian konsentrasi ekstrak etanol daun jeruk purut yang berbeda (Tabel 1). Perbedaan yang signifikan terhadap antibiotik kloramfenikol ini menunjukkan bahwa pada pemberian konsentrasi ekstrak etanol daun jeruk purut sebesar $6,25 \%, 12,5 \%, 25 \%, 50 \%$, dan $100 \%$ mampu meningkatkan besar diameter zona hambat pertumbuhan Bacillus cereus secara signifikan.

Selain itu, hasil penelitian ini didukung oleh hasil penelitian sebelumnya tentang adanya kandungan zat aktif dengan aktivitas antibakteri pada ekstrak etanol daun jeruk purut (Citrus hystrix D.C).4,5 Aktivitas antibakteri ekstrak etanol daun jeruk purut juga telah dievaluasi efeknya terhadap beberapa bakteri lain pada penelitian sebelumnya, di antaranya terhadap bakteri basil Gram negatif Vibrio cholerae dan Escherichia coli yang mulai sensitif pada konsentrasi $7 \%$. Sementara hasil terhadap $E$. coli mulai sensitif pada konsentrasi $10 \%, 6,7$

Merujuk pada hasil penelitian terhadap kedua bakteri Gram negatif tersebut, maka dibutuhkan konsentrasi ekstrak etanol daun jeruk purut yang lebih tinggi untuk dapat memberikan efek antibakteri terhadap basil Gram negatif, dibandingkan dengan efeknya terhadap basil Gram positif (Bacillus cereus). 
Hal ini selaras dengan sifat dari morfologi sel yang berbeda antara bakteri Gram positif dan negatif. Bakteri Gram negatif memiliki struktur dinding sel yang lebih kompleks dari bakteri Gram positif. Selain itu, terdapat molekul lipopolisakarida pada membran terluar bakteri Gram negatif yang tidak dimiliki oleh bakteri Gram positif yang membuat bakteri Gram negatif cenderung kurang sensitif terhadap zat antibakteri. ${ }^{14,15}$

Dari hasil penelitian ini serta penelitian terdahulu menunjukkan bahwa ekstrak etanol daun jeruk purut memiliki aktivitas antibakteri baik terhadap bakteri Gram positif maupun bakteri Gram negatif. Hal ini berarti aktivitas antibakteri ekstrak etanol daun jeruk purut dapat dikatakan berspektrum luas karena dapat menargetkan pada kedua bakteri baik Gram negatif maupun positif.

Selain efek antibakteri terhadap bakteri Gram postitif dan negatif, telah dinilai juga efek antijamur dari ekstrak etanol daun jeruk purut. Dari penelitian sebelumnya yang dilakukan oleh Lindariyanti, terbukti bahwa ekstrak etanol daun jeruk purut memiliki efek antibakteri terhadap jamur Colletotrichum gloeosporioides Penz. Sacc., dengan diameter zona hambat pertumbuhan yang terbentuk sebesar $11,37 \mathrm{~mm}$ pada konsentrasi $50 \% .{ }^{16}$ Hal ini menunjukkan bahwa ekstrak etanol daun jeruk purut juga memiliki efek terhadap pertumbuhan jamur. Apabila dibandingkan efeknya terhadap $B$. cereus, ekstrak etanol daun jeruk purut lebih efektif dalam menghambat pertumbuhan jamur daripada menghambat pertumbuhan bakteri.

Selain itu, beberapa penelitian telah meneliti efek herbal lain sebagai antibakteri terhadap Bacills cereus. Dibandingkan hasil efek antibakteri ekstrak etanol daun jeruk purut dengan hasil efek antibakteri herbal lain terhadap bakteri Bacillus cereus, diketahui bahwa ekstrak etanol daun jeruk purut kurang poten terhadap $B$. cereus apabila dibanding- kan efeknya dengan ekstrak angkak (Monascus purpureus) yang telah menghambat pertumbuhan bakteri pada konsentrasi $4 \%$, dan ekstrak rumput laut (Eucheuma cottonii) yang telah menghambat pertumbuhan bakteri pada konsentrasi $4 \%$. Namun, jika dibandingkan efeknya dengan sari daun binahong (Anredera cordifolia) yang menghambat pertumbuhan bakteri pada konsentrasi $25 \%$, ekstrak etanol daun jeruk purut (Citrus hystrix D.C) lebih efektif menghambat pertumbuhan bakteri Bacillus cereus. ${ }^{17,18,19}$

\section{Kesimpulan}

Ekstrak etanol daun jeruk purut (Citrus hystrix D.C) mulai efektif sebagai antibakteri tehadap Bacillus cereus pada konsentrasi $6,25 \%$ dengan sensitivitas antibakteri kategori sedang secara in vitro. Dibandingkan dengan efeknya terhadap kloramfenikol, ekstrak etanol daun jeruk purut mampu menghambat pertumbuhan Bacillus cereus secara signifikan.

\section{Daftar Pustaka}

1. Haque M, Sartelli M, McKimm J, Abu Bakar M. Health Care-Associated Infections: an Overview. Infection and Drug Resistance. 2018; 11:2321-2333.

2. Centers for Disease Control and Prevention (CDC). Healthcare-Associated Infections. (Online). 2017. https:// www.cdc.gov/winnablebattles/report/ HAls.html. diakses 8 Apr. 2019.

3. Glasset B, Herbin S, Granier S, Cavalié L, Lafeuille $E$, Guérin $C$ et al. Bacillus cereus, a Serious cause of Nosocomial Infections: Epidemiologic and Genetic Survey. PLOS ONE. 2018; 13 (5):e0194346. 
4. Ali $M$, Akhter $R$, Najah Narjish $S$, Shahriar M, Ahmed Bhuiyan M. Studies of Preliminary Phytochemical Screening, Membrane Stabilizing Activity, Thrombolytic Activity and In-Vitro Antioxidant Activity of leaf Extract of Citrus hystrix D.C. International Journal of Pharmaceutical Sciences and Research. 2015; 6(6):2367-2374.

5. Arfania M. Telaah Fitokimia Ekstrak Etanol Daun Jeruk Purut (Citrus hystrix D.C) di Kabupaten Karawang. Jurnal IImu Farmasi. 2017; 2(2):131-135.

6. Melany. Efektivitas Ekstrak Etanol Daun Jeruk Purut (Citrus hystrix D.C) sebagai Antimikroba terhadap Vibrio cholerae Isolat Standar secara In Vitro. Skripsi. Tidak Diterbitkan. Universitas Brawijaya. Malang. 2014.

7. Nadyasari N. Daya Antibakteri Ekstrak Etanol Daun Jeruk Purut (Cytrus hystrix D.C.) terhadap Bakteri Escherichia coli serta Kesetaraannya terhadap Kloramfenikol. Skripsi. Universitas Surabaya. Surabaya. 2007.

8. Nugroho, A. Buku Ajar: Teknologi Bahan Alam. Banjarmasin: Lambung Mangkurat University Press. 2017. HIm. 72-89.

9. Wiegand I, Hilpert K, Hancock R. Agar and Broth Dilution Methods to Determine the Minimal Inhibitory Concentration (MIC) of Antimicrobial Substances. Nature Protocols. 2008; 3(2):163-175.

10. Balouiri, M., Sadiki, M. and Ibnsouda, S. Methods for In Vitro Evaluating Antimicrobial Activity: A Review. Journal of Pharmaceutical Analysis. 2016; 6 (2):71-79.

11. Sugiyono S. Metode Penelitian Kuantitatif Kualitaif dan R\&D. Bandung: Alfabeta; 2007.

12. Lestari $Y$, Ardiningsih $P$, Nurlina $N$. Aktivitas Antibakteri Gram Positif dan Negatif dari Ekstrak dan Fraksi Daun
Nipah (Nypa fruticans Wurmb.) Asal Pesisir Sungai Kakap Kalimantan Barat. Jurnal Kedokteran dan Kesehatan. 2016; 5(4):1-4.

13. Davis W, Stout T. Disc Plate Method of Microbiological Antibiotic Assay. Applied Microbiology. 1971; 22(4):659-665.

14. Albrecht T, Baron S. Medical Microbiology. Galveston, Tex.: University of Texas Medical Branch at Galveston, Dept. of Microbiology \& Immunology. 1996.

15. Breijyeh Z, Jubeh B, Karaman R. Resistance of Gram-Negative Bacteria to Current Antibacterial Agents and Approaches to Resolve It. Molecules. 2020; 25(6):1340.

16. Lindariyanti, AZ. Pengaruh Berbagai Konsentrasi Ekstrak Daun Jeruk Purut (Citrus hystrix D.C) terhadap Zona Hambat Jamur Colletotrichum gloeosporioides (Penz.) Sacc. sebagai Kajian Analisis Sumber Belajar. Skripsi. Tidak Diterbitkan. Universitas Muhammadiyah Malang. Malang. 2019.

17. Sumaryati E, Sudiyono S. Kajian Aktivitas Antibakteri Ekstrak Angkak terhadap Pertumbuhan Bakteri Bacillus cereus dan Bacillus stearothermophillus. Jurnal Teknologi Pangan. 2015: 6(1):1-11.

18. Hutabarat M.A.A, Sari N.I, Leksono T. Uji Efektivitas Antibakteri Ekstrak Rumput Laut (Eucheuma cottonii) terhadap Bakteri Bacillus cereus dan Pseudomonas aeruginosa. Skripsi. Tidak Diterbitkan. Universitas Riau. Pekanbaru. 2016.

19. Rahmawati F, Bintari S.H. Studi Aktivitas Antibakteri Sari Daun Binahong (Anredera cordifolia) Terhadap Pertumbuhan Bacillus cereus dan Salmonella enteritidis. Unnes Journal of Life Science. 2014; 3(2). 